\title{
Sürücü Kursları Direksiyon Eğitimi Sınav Değerlendirme Ölçütlerinin Pareto Analizi Yöntemi ile İncelenmesi
}

\author{
Seda Hatipoğlu ${ }^{*}$ \\ ${ }^{1}$ Trafik Planlaması ve Uygulaması Anabilim Dalı, Gazi Üniversitesi, Ankara, Türkiye
}

Öz

Türkiye'de trafik kuralları, sürücü belgesi alma süreçleri, 2918 sayılı Karayolları Trafik Kanunu'nda belirlenmiştir. Trafik Kanunu gereği, Türkiye'de sürücü belgesi almak isteyen bir kursiyerin, 5580 sayılı Özel Öğretim Kurumları Kanunu kapsamında açılmış özel motorlu taşıt sürücü kurslarına devam etmesi ve eğitimini tamamlayarak Milli Eğitim Bakanlığı (M.E.B) tarafından yapılacak teorik ve direksiyon eğitimi sınavlarında başarılı olması gerekmektedir. Konu ile ilgili literatür incelendiğinde, sürücü kurslarında verilen teorik eğitim ve sınavı ile ilgili birçok çalışmaya rastlanmakla birlikte direksiyon eğitimi sınavı ve sınav değerlendirme ölçütlerinin etkinliği konusunda çalışma yapılmadığı görülmüştür. Bu çalışmada, 2018 senesinde yapılan direksiyon sınavlarında sürücü adaylarının yapmış oldukları hatalar "Direksiyon Eğitimi Dersi Sınav Değerlendirme Formu”nda yer alan 18 başlık ve 125 önermeye göre sınıflandırılmıștır. Bu sınıflandırma Pareto analizi yöntemi ile değerlendirilmiş ve önemli azınlığı oluşturan başlık ve önermeler tespit edilmiştir. Pareto analizi yapıldığında 18 hata başlı̆̆ından 5 tanesinin tüm grubun \%83,5’ini oluşturduğu görülmüştür. Bunlar sırasıyla; geri geri park etme, kalkış yapma (aracı harekete geçirme), araç bilgisi sorgulama, eğimli yolda kalkış, geri giderken sağa-sola (L) dönmedir. Çalışmanın devamında belirlenen bu başlıklar kendi içlerinde analiz edilmiş ve elde edilen sonuçlar tartışmaya açılmıştır.

Anahtar Kelimeler: sürücü, sürücü eğitimi, direksiyon sınavı, Pareto analizi

\section{Examination of Driving Courses Steering Training Exam Evaluation Criteria Using Pareto Analysis Method}

\begin{abstract}
Traffic rules in Turkey, the process of getting a driver's license are all determined in the Highway Traffic Laws number 2918. A trainee who want to get the driver's license Turkey, should continue to private motor vehicle driving courses opened according to 5580 Private Education Institutions to and needs to be successful in both theoretical and steering exams made by the Ministry of Education. When the literature on the subject is examined, it has been observed that although there are many studies on the theoretical training and exams given in driving courses, no studies have been conducted on the effectiveness of the driving training exam and exam evaluation criteria. In this study, the mistakes made by the candidate drivers in the steering exams held in 2018 were classified according to 18 titles and 125 propositions in the "Steering training course exam evaluation form". This classification was evaluated with the Pareto analysis method and the titles and propositions that constitute the important minority were determined. When a pareto analysis was made, it was observed that 5 of the 18 error titles constituted $83.5 \%$ of the entire group. These are respectively; back parking, taking off (activating the vehicle), questioning vehicle information, taking off on the inclined road, turning right-left (L) while going back. These titles determined in the continuation of the study were analyzed within themselves and the results obtained were opened for discussion.
\end{abstract}

Keywords: driver, driver training, steering exam, Pareto analysis

\footnotetext{
* İletişim / Contact: Seda Hatipoğlu, Trafik Planlaması ve Uygulaması Anabilim Dalı, Gazi Üniversitesi, Ankara, Türkiye, Eposta:sedab@gazi.edu.tr Gönderildiği tarihi / Date submitted: 15.05.2020, Kabul edildiği tarih / Date accepted: 05.10.2020 Alıntı / Citation: Hatipoğlu, S. (2020). Sürücü Kursları Direksiyon Eğitimi Sınav Değerlendirme Ölçütlerinin Pareto Analizi Yöntemi ile İncelenmesi. Trafik ve Ulaşım Araştırmaları Dergisi, 3(2), 121-132. doi:10.38002/tuad.773877
} 


\section{Sürücü Kursları Direksiyon Eğitimi Sınav Değerlendirme Ölçütlerinin Pareto Analizi Yöntemi ile İncelenmesi}

\subsection{Sürücü Kursları Eğitimi}

\section{Giriş}

Karayolları Trafik Kanunu gereği, Türkiye'de sürücü belgesi almak isteyen bir kişinin, Özel Öğretim Kurumları Kanunu kapsamında açılmış “Özel Motorlu Taşıt Sürücüleri Kursu”na devam etmesi ve eğitimini tamamlayarak Millî Eğitim Bakanlığınca yapılacak teorik ve direksiyon eğitimi sınavlarında başarılı olması gerekmektedir.

Sürücü kurslarında eğitim, teorik ve pratik eğitim olarak iki aşamalı verilmektedir. Sürücü kursu teorik eğitimi bütün sertifika sınıflarında, Trafik ve Çevre dersi 16 saat, İlk Yardım dersi 8 saat, Araç Tekniği dersi 6 saat ve Trafik Adabı dersi 4 saat olmak üzere 34 saat olarak verilir. Kursiyerlerin direksiyon eğitimine (pratik eğitime) başlamadan önce teorik dersleri tamamlamaları gerekmektedir. Pratik eğitim ders saati sayısı ise minimum 14 saat olarak belirlenmiştir. 14 saat sonunda kursiyere eğitim veren usta öğretici kursiyeri yeterli görmez ise eğitimi uzatabilir.

Direksiyon eğitimi dersi uygulama sınavlarında kursiyerlerin temel araç hâkimiyeti yanında, trafik kurallarına uygun ve trafik güvenliğini tehlikeye sokmayacak şekilde araç kullanmaları istenir. 35 dakikalık uygulama sınavı süresi içerisinde kursiyerin trafikte kural hatası yapması veya araç hâkimiyeti açısından sürücü belgesi alamayacak kanaatinin oluşması durumunda bu süre bitmeden kursiyerin sınavı sona erdirilir. Kursiyerin yapmış olduğu hatalı davranış tablet üzerinde bulunan MEBDUS (MEB Direksiyon Sınavı Uygulaması) programının içinde kayıtlı olan Direksiyon Eğitimi Dersi Sınav Değerlendirme Formu'na işlenir. (Ek-1).

Türkiye'de direksiyon eğitimi sınavı değerlendirme sistemi aşamalı olarak gelişmeye devam etmektedir. Bu gelişmeye katkı sağlamak amacı ile yapılan çalışmada; direksiyon sınavı değerlendirme ölçütleri sürücü adaylarının sınavda yaptıkları hata dağılımına göre incelenmiştir. Yapılan literatür araştırmasında, konu ile ilgili çalışmaların, sürücü kursları teorik sınav performans değerlendirmeleri (Güleç, 2011), teorik sınavın elektronik ortamda yapılmasının gerekliliği (Doğru, 2018), ders müfredatı ve teorik sınavın geliştirilmesi (Selbes, 2008; Selvi, 2009) gibi sürücü kurslarında verilen teorik eğitimin geliştirilmesi üzerine yoğunlaştığ1 görülmektedir. Vursavaş (2004), Gülecen (1998) ve Aşıkkaya (1995) tarafından yapılan çalışmalarda direksiyon sınavı iyileştirilmesi yönünde öneriler getirilmiş olsa da çalışmaların güncel olmaması nedeniyle şu anki sınav sistemini kapsamamaktadır. Bu nedenle yapılan bu çalışmanın ulusal literatüre katkı sağlayacağı düşünülmektedir.

Çalışmada analiz yöntemi olarak Pareto Analizi Kuralı kullanılmıştır.

\subsection{Pareto Analizi Kuralı}

Pareto analizi, İtalyan ekonomist Vilfredo Pareto'nun 1897 yılında İtalya'daki servetin \%80'ine nüfusunun \%20'sinin, İngiltere'deki toprakların \%80'ine ise nüfusunun \%20'sinin sahip olduğunu gözlemlemesiyle ortaya çıkmıştır. Servet dağılımına ilişkin daha sonraki incelemelerinde de bu oranların genelde aynı olduğunu tespit etmiştir (Tatikonda, O’Brien ve Tatikonda, 1999).

Pareto daha sonra, bahçesinde ektiği bezelye tohumlarının \%20'sinin, mahsulün \%80'ini verdiğini de tespit etmesiyle birlikte bu incelemelerinden önemli azınlık ile önemsiz çoğunluğa ilişkin matematiksel bir modelin var olabileceğini keşfetmiştir (Mc Cann, 2001). Pareto'nun matematiksel modelinin 80/20 kuralıyla bağlantısı ise Joseph M. Juraririm

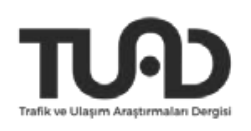


gözlemleri ve bu gözlemlerine ilişkin yazılarının sonucunda gerçekleşmiştir (Craft ve Leake, 2002).

Pareto analizinden; sorunlara yol açan ana sebepler üzerinde hızlı bir biçimde odaklanabilinmesinde, belirli bir durum için neyin en önemli olduğuna karar verebilmek için problemin ana sebebinin belirlenmesinde ve veri toplama işleminin incelenmesinde yararlanılır. Yine bu analizde en önemli birkaç konu veya sorun üzerinde dikkat yoğunlaştırıldığından ve önceliklerin belirlenmesine yardımcı olduğundan, verimlilik analizi için de yararlı bir araçtır (Başaran, 2010).

Zinebi, Souissi ve Tikito (2018), Fas'ta sürücü davranışlarının trafik kazası üzerine etkilerini Pareto analizi yardımıyla sınıflandırmışlardır. Pareto grafiği temel alınarak hazırlanacak bir sürücü eğitim modelinin trafik kazalarını azaltmadaki etkisini tartışmaya açmışlardır. Benzer bir çalışma Ziarati (2006) tarafından deniz güvenliği için yapılmış ve deniz ve liman güvenliği için önceliklendirme tablosu oluşturulmuştur. Kujala, Weckström, Mladenovic ve Saramaki (2018), Pareto yöntemiyle toplu taşım yolculuklarının tercih edilme nedenlerini sıralayarak talebi ve verimliliği arttırmayı hedeflemişlerdir.

Pareto analizi yapılması ve Pareto grafiği oluşturulması altı adımda incelenebilir (Özcan, 2001). İlk adımda tüm önermeler belirlenir, gruplanır ve listelenir. İkinci adımda her bir önermenin hata sayısı belirli bir zaman aralığında ölçülür ve kayıt altına alınır. Üçüncü adımda önermeler hata sayısına göre büyükten küçüğe sıralanır ve tablo oluşturulur. Dördüncü adımda, her bir önermenin toplam içindeki yüzde değeri bulunup, kümülatif toplamları hesaplanır. Beşinci adımda, y ekseninde hata sayıları, x ekseninde en büyük değerden başlamak üzere hata sebepleri yer alan Pareto grafiği çizilir. Altıncı adımda ise elde edilen Pareto grafiği yorumlanır

\section{Yöntem}

Çalışma kapsamında; MEB Özel Öğretim Kurumları Genel Müdürlüğü Trafik ve Sürücü Eğitimleri Daire Başkanlığına 4982 sayılı Bilgi Edinme Hakkı Kanunu kapsamında kişisel olarak başvurulmuştur. Kamu ve özel hayatı etkilemeyen ve kişisel bilgi edinme kanuna aykırı olmayacak "sürücü belgesi" ile ilgili veriler araştırmacıya elektronik ortamda verilmiştir. Veri paketini; 76.491 sürücü adayının il, ilçe, devam ettiği sürücü kursu ve direksiyon sınavında yapmış olduğu hata numaraları oluşturmaktadır. Veriler Mart 2018-Mart 2019 arası olmak üzere bir senelik istatistikleri kapsamaktadır. Sürücü adaylarının direksiyon sınavı esnasında yapmış oldukları hatalar "Direksiyon Eğitimi Dersi Sınav Değerlendirme Formu"nda yer alan hata başlıklarına göre excel programı yardımı ile analiz edilmiş ve sınıflandırılmıştır. Elde edilen sonuçlar Pareto Yöntemi uygulama adımları takip edilerek analiz edilmiş ve yorumlanmıştır.

Birinci aşamada yapılan analiz sonucu önemli azınlık başlıkları belirlenmiştir. İkinci aşamada ise bu başlıklara kendi içlerinde Pareto analizi uygulanmış böylece en önemli önermeler saptanmıştır.

\section{Bulgular}

Direksiyon Eğitimi Dersi Sınav Değerlendirme Formu 18 başlık altında sınıflandırılmış 125 önermeden oluşmaktadır. Sürücü adaylarının bu 125 önermede yapmış oldukları toplam hata 898.618' dir. Sinavda yapılan hatalar Excel programı yardımıyla önce önermeler bazında toplanmış daha sonra başlıklar altında gruplandırılmıştır.

18 ana başlıktan her birine ait hata sayıları ve bu hataların adet ve yüzde olarak kümülatif toplamları Tablo 1'de verilmiştir.

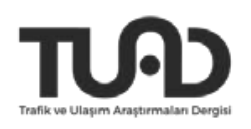


Pareto analizi yapıldığında 18 hata başlığından 5 tanesinin tüm grubun \%83,5'ini oluşturduğu görülmüş̧ür. Bunlar sırasıyla; geri geri park etme, kalkış yapma (aracı harekete geçirme), araç bilgi sorgulama, eğimli yolda kalkış, geri giderken sağa-sola (L) dönmedir.

Tablo 1. Hata başlıklarının kümülatif sıralaması

\begin{tabular}{|c|c|c|c|c|}
\hline Hata & Adet & $\begin{array}{c}\text { Toplam } \\
\text { Adet }\end{array}$ & Yüzde (\%) & Kümülatif (\%) \\
\hline Geri geri park etme & 239465 & 239.465 & 28,0 & 28,0 \\
\hline Kalkış yapma (aracı harekete & & & 24,8 & \\
\hline geçirme) & 235256 & 474.721 & & 52,8 \\
\hline Araç Bilgi Sorgulama & 136076 & 610.797 & 15,2 & 68,0 \\
\hline Eğimli yolda kalkış & 71301 & 682.098 & 7,9 & 75,9 \\
\hline Geri giderken sağa-sola (L) dönme & 68038 & 750.136 & 7,6 & 83,5 \\
\hline Araç seyir halindeyken & & & 3,1 & \\
\hline değerlendirilecek davranışlar & 28493 & 778.629 & & 86,6 \\
\hline Direksiyon hakimiyeti & 22184 & 800.813 & 2,5 & 89,1 \\
\hline Araç kumanda pedallarına intibak & 18450 & 819.263 & 2,1 & 91,2 \\
\hline Kavşaklara yaklaşma ve & & & 2,0 & \\
\hline kavşaklarda sağa sola dönüşler & 18286 & 837.549 & & 93,2 \\
\hline Geri geri düz gitme (25 mt) & 17791 & 855.340 & 2,0 & 95,2 \\
\hline Şerit izleme ve değiştirme & 12124 & 867.464 & 1,3 & 96,5 \\
\hline Duraklama ve park etme & 10288 & 877.752 & 1,2 & 97,7 \\
\hline Ani fren yapma & 9955 & 887.707 & 1,1 & 98,8 \\
\hline Aracı çalıştırma & 5250 & 892.957 & 0,6 & 99,4 \\
\hline H1z Kuralları & 3984 & 896.941 & 0,4 & 99,8 \\
\hline Çevreye duyarlı ve ekonomi $\mathrm{k}$ araç & & & 0,2 & \\
\hline kullanma & 1677 & 898.618 & & 100,0 \\
\hline $\begin{array}{l}\text { Önündeki aracı geçme (sollama } \\
\text { yapma) }\end{array}$ & - & 898.618 & - & 100,0 \\
\hline $\begin{array}{l}\text { Koltuk, ayna, emniyet kemeri, } \\
\text { alkol }\end{array}$ & - & 898.618 & - & 100,0 \\
\hline
\end{tabular}

Pareto analizi tablosu yardımıyla Pareto grafiği oluşturulmuştur (Şekil 1). 


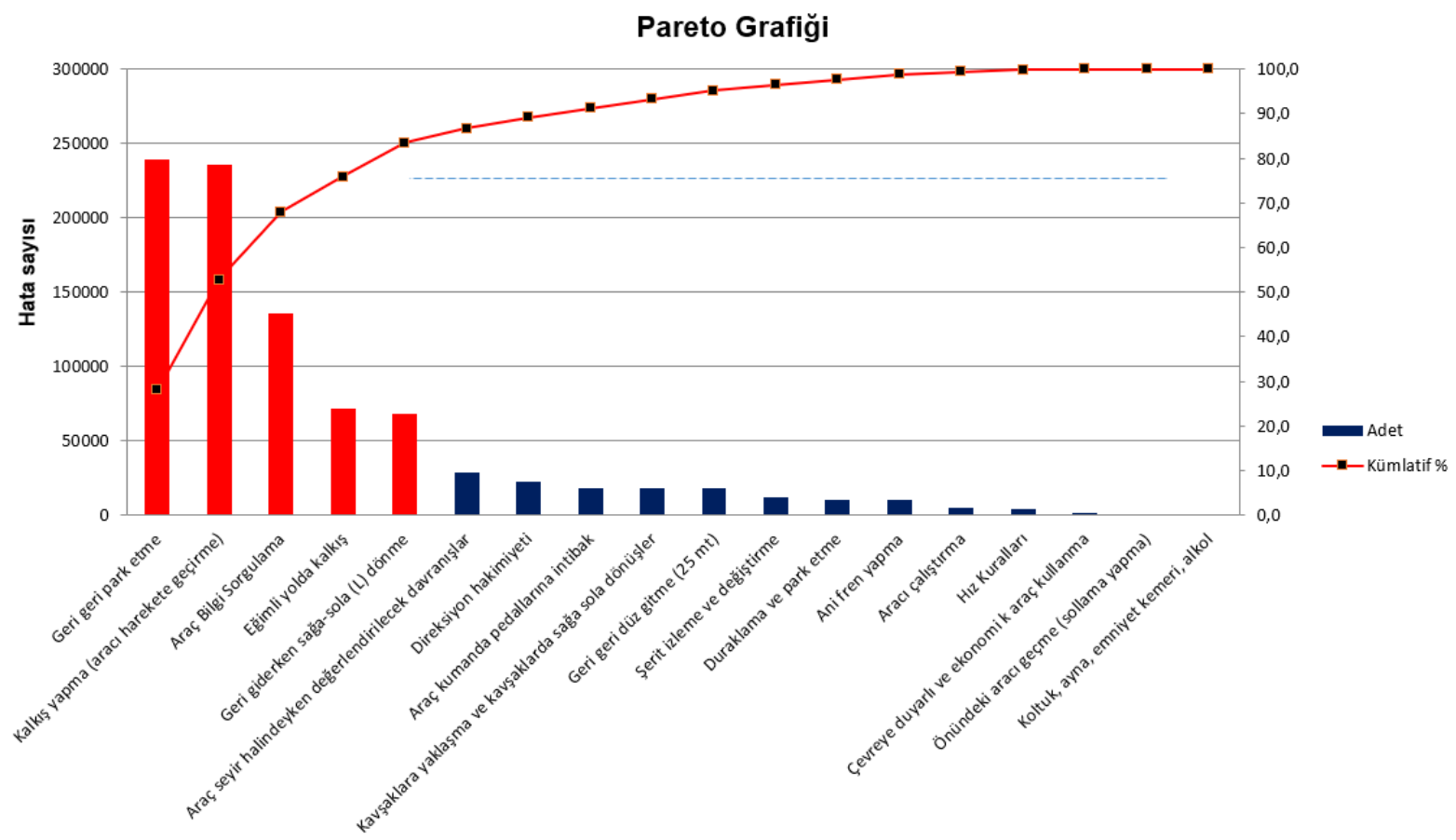

Şekil 1. Pareto Grafiği

Hazırlanan Pareto grafiğinde (Şekil 1) kesik çizgili kısım \%80’lik önemlilik kısmını oluşturmaktadır. Çalışmada 18 hata başlığı bulunmakta ve kırmızı ile gösterilen 5 tanesi önemli azınlığı oluşturmaktadır. Bu başlıklar altında yapılan hata sayısı 750.136'dır. Diğer 13 hata başlığı ise önemsiz çoğunluğu oluşturmaktadır. Bu başlıklar altında yapılan hata sayısı ise 148.482 'dir.

Ek 1'de de görüleceği üzere her bir başlık altında adayların yapmış oldukları hata önermeleri bulunmaktadır. Adayların en fazla hata yaptıkları önermeleri belirlemek amacı ile, yukarıda tespit edilen ve en fazla yapılan hata başlıkları kendi içlerinde (önermeler bazında) Pareto analizine tabi tutulmuştur (Tablo 2).

Tablo 2. Başlıkların önermeler bazında kümülatif sıralandırılması

\begin{tabular}{|c|c|c|c|}
\hline \multicolumn{4}{|c|}{ Geri geri park etme } \\
\hline Önerme & Hata Adedi & Yüzde (\%) & Kümülatif (\%) \\
\hline $\begin{array}{l}\text { Park ederken veya park alanından } \\
\text { çıkarken kaldırıma veya konilere } \\
\text { çarpıyor. }\end{array}$ & 101.071 & 42,21 & 42,21 \\
\hline $\begin{array}{l}\text { Kaldırıma } 50 \mathrm{~cm} \text { 'den fazla açığa } \\
\text { park ediyor. }\end{array}$ & 45.207 & 18,88 & 61,04 \\
\hline $\begin{array}{l}\text { Koniler arasında (İçeride) en fazla } \\
\text { iki hamlede park edemiyor }\end{array}$ & 36.434 & 15,21 & 76,25 \\
\hline $\begin{array}{l}\text { Koniler arasina tek hamlede } \\
\text { giremiyor. }\end{array}$ & 32.218 & 13,45 & 89,70 \\
\hline Diğer & 24.535 & 10,30 & 100,00 \\
\hline \multicolumn{4}{|c|}{ Kalkış yapma (aracı harekete geçirme) } \\
\hline $\begin{array}{l}\text { Kalkış yaparken motoru stop } \\
\text { ettiriyor. }\end{array}$ & 192.576 & 81,56 & 81,56 \\
\hline Diğer & 42.680 & 18,14 & 100,00 \\
\hline
\end{tabular}




\begin{tabular}{|c|c|c|c|}
\hline \multicolumn{4}{|c|}{ Eğimli Yolda Kalkış } \\
\hline Önerme & Hata Adedi & Yüzde (\%) & Kümülatif (\%) \\
\hline $\begin{array}{l}\text { Kalkış yaparken motoru stop } \\
\text { ettiriyor. }\end{array}$ & 61.208 & 85,84 & 85,84 \\
\hline Diğer & 10.093 & 14,16 & 100,00 \\
\hline \multicolumn{4}{|c|}{ Geri geri giderken sağa sola $(\mathrm{L})$ dönme } \\
\hline $\begin{array}{l}\text { Geri giderken konilere veya } \\
\text { kaldırıma çarpıyor, şeridinin } \\
\text { dışına çıkıyor. }\end{array}$ & 44.582 & 65,53 & 65,53 \\
\hline $\begin{array}{l}\text { Geri giderken şeridini koruyarak } \\
\text { köşeden sağa ya da sola tek } \\
\text { hamlede dönemiyor ( } 90 \text { derece açı } \\
\text { ile). }\end{array}$ & 12.696 & 18,66 & 84,19 \\
\hline Diğer & 10.760 & 15,81 & 100,00 \\
\hline
\end{tabular}

Belirlenen 5 ana başlıktan biri olan "Araç Bilgisi Sorgulama" tabloya dahil edilmemiştir. Çünkü; bu başlığın altında 14 önerme bulunmaktadır ve toplamda 136.076 hata yapılmıştır. Hata paylarına bakıldığında \%4.05-\%11.93 arasında değişen homojene yakın dağılım görülmektedir. Pareto analizinin hedeflediği \%80'lik kümülatif toplam değerine ancak onuncu önermede ulaşılabilmiştir. Bu nedenle "Araç Bilgisi Sorgulama" bölümü altında yapılan hatalarda bir Pareto analizine göre bir önceliklendirme yapılması anlamlı bir sonuç vermeyecektir. $\mathrm{Bu}$ başlık için en fazla hata yapılan 3 önerme sıralanmış ve yorum bunun üzerinden yapılmıştır.

- Lastiklerin havalarının yeterli olup olmadığını gözle veya ayakla kontrol etmiyor.

- Uzun/kısa far, korna, cam silecek ve diğer kumanda kollarını gösteremiyor.

- Motor yağ1 ve motor suyu konulma yerini gösteremiyor

\section{Tartışma}

Yapılan çalışmada elde edilen bulgular incelendiğinde;

Direksiyon Eğitimi Dersi Sınav Değerlendirme Formu'na göre 125 önermeden oluşan 18 başlık içinde Pareto analizine göre \%80'lik önem sırasını geçen beş başlık belirlenmiştir. Bunlar; geri geri park etme, kalkış yapma (aracı harekete geçirme), araç bilgi sorgulama, eğimli yolda kalkış ve geri giderken sağa-sola (L) dönmedir.

$\mathrm{Bu}$ hata başlıkları Pareto analizi ile kendi içlerinde değerlendirildiğinde Pareto analizine göre \%80 barajını geçen hatalar aşağıda sıralanmıştır.

$\checkmark \quad$ Park ederken veya park alanından çıkarken kaldırıma veya konilere çarpıyor (geri geri park etme)

$\checkmark \quad$ Kaldırıma $50 \mathrm{~cm}$ 'den fazla açığa park ediyor (geri geri park etme)

$\checkmark \quad$ Koniler arasında (içeride) en fazla iki hamlede park edemiyor (geri geri park etme)

$\checkmark \quad$ Koniler arasına tek hamlede giremiyor (geri geri park etme)

$\checkmark \quad$ Kalkış yaparken motoru stop ettiriyor (kalkış yapma-aracı harekete geçirme)

$\checkmark \quad$ Kalkış yaparken motoru stop ettiriyor (eğimli yolda kalkış)

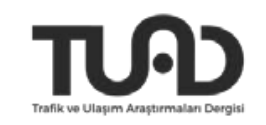


$\checkmark \quad$ Geri giderken konilere veya kaldırıma çarpıyor, şeridinin dışına çıkıyor. (Geri geri giderken sağa sola (L) dönme)

$\checkmark \quad$ Geri giderken şeridini koruyarak köşeden sağa ya da sola (90 derece açı ile) tek hamlede dönemiyor (Geri geri giderken sağa sola (L) dönme)

Bu sekiz önermenin dört tanesinin park problemi, iki tanesinin kalkış problemi, iki tanesinin ise geri geri gidiş problemi olduğu görülmektedir.

Araç Bilgisi Sorgulama başlığı altındaki 14 önermenin hata payları \%4.05-\%11.93 arasında değişen homojene yakın dağılım gösterdiğinden Pareto analizine göre bir önceliklendirme yapılamamıştır.

Direksiyon sınavında park etme hatasının türel dağılımdaki payının en fazla olması iki farklı bakış açısıyla tartışılması gereken bir konudur. Birinci bakış açısıyla; direksiyon eğitiminde park etme becerisinin sürücü adaylarına tam olarak verilemediği ve bu konunun dersteki etkinliğinin artırılması gerekliliği tartışmaya açılmalıdır. Diğer bakış açısıyla ise, gelişen araç teknolojisi ile (araç kameraları, park sensörleri, vb.) park edebilmenin insan becerisinden daha çok araç teknolojisi ile yapılabilir olduğu günümüzde, tecrübe ile gelişecek park edebilme yetisinin test edilmesinin sinavda gereğinden fazla baskın bir değerlendirme önermesi olduğunun tartışmaya açılmasıdır.

Yapılan Pareto analizi sonucu gerek düz yolda gerekse eğimli yolda ilk kalkış hatasının \%80'lik bölümün içinde olması sürücü adaylarının sınav heyecanı taşımaları ile yorumlanabilir. Özellikle ilk kalkış, bilgi sorularından sonra adayın sürücü pozisyonunda sınava ilk başlama halidir. Bu noktadaki başarısızlığın sebebinin sınav kaygısı olabileceği düşünülmektedir. Sınav kaygısı performansın esas habercisi konumundadır ve pek çok çalışma sınav kaygısının temelde zarar verici bir yapısı olduğunu göstermiştir (Sazak ve Ece, 2004). Sınav öncesi ya da sınav anında, öğrencinin aklından geçen, engelleyemediği olumsuz düşünceleri sınav kaygısının kaynağı olarak gören karıştırıcı değişkenler modeli oldukça kabul görmektedir. Sadece olumsuz otomatik düşünceler ya da sınava ilişkin akılcı olamayan inançlar değil, sınavın sonucunun nasıl kullanılacağına ilişkin edinilen bilgiler ve değerlendirme stiline ilişkin algılar da sınav kaygısı üzerinde etkili olmaktadır. Sınava giren kişinin yaşadığı tüm bu düşünce karmaşası içerisinde ortaya koyduğu performansa odaklanamaması, sınav esnasındaki başarısına da direkt etkilidir (Bozanoğlu, 2005).

En fazla yapılan hatalardan biri de "geri geri sağa sola (L) dönme" başlığına aittir. Bu başlığa kendi içinde Pareto analizi uygulandığında \%80 hata dilimin içine giren önermeler; "geri giderken konilere veya kaldırıma çarpıyor, şeridinin dışına çıkıyor" ve "geri giderken şeridini koruyarak köşeden sağa ya da sola (90 derece açı ile) tek hamlede dönemiyor”dur. Her iki önermede de dikkat çekici nokta adayın geri giderken şeridini koruyamadığ 1 olmaktadır. Araçla geri gidebilmek ve geri dönüş yapabilmek tekrar ve tecrübe ile mümkündür.

Yine yapılan Pareto analizine göre "araç bilgisi sorgulama" bölümü yapılan tüm hataların \%80 ini oluşturan dilime girmektedir. Araç bilgisi 14 önermede sorgulanmakta olup, kendi içinde Pareto analizi yapıldığında anlamlı bir sonuç elde edilememektedir.

\section{Sonuç ve Öneriler}

Yapılan bu çalışmada; sürücü adaylarının direksiyon sınavında yapmış oldukları hatalar “Direksiyon Eğitimi Dersi Sınav Değerlendirme Formu”nda yer alan 18 başlık ve 125 önermeye göre sınıflandırılmıştır. Bu sınıflandırma Pareto analizi yöntemi ile değerlendirilmiş ve önemli azınlığı oluşturan başlık ve önermeler tespit edilmiş ve bulgular kısmında ortaya konulmuştur. Çalışmanın tartışma bölümünde elde edilen bulgular farklı bakış açıları ile 
tartışmaya sunulmuştur. Tüm bu çalışmalar 1şığında elde edilen sonuç ve öneriler aşağıda özetlenmiştir.

Pareto analizi yapıldığında 18 hata başlığından 5 tanesinin tüm grubun \%83,5'ini oluşturduğu görülmüştür. Bunlar sırasıyla; geri geri park etme, kalkış yapma (aracı harekete geçirme), araç bilgi sorgulama, eğimli yolda kalkış, geri giderken sağa-sola (L) dönmedir.

"Direksiyon Eğitimi Dersi Sınav Değerlendirme Formu" başlıkları ve önermeleri incelendiğinde (Ek1) "kavşaklara yaklaşma ve dönüşler, şerit izleme, direksiyon hakimiyeti, hız kuralları, sollama yapma gibi trafik güvenliğini birincil derecede etkileyecek önermelerin sürücü adayları tarafından daha iyi algılandığ 1 ve bu konularda sınavda daha az hata yapıldığ görülmektedir.

Pareto analizine göre, park etme hatası birden fazla önerme ile \%80’lik dilimin içinde bulunmaktadır. Araştırmacı tarafından, park edebilmenin trafik güvenliğini birincil derecede etkilememesi ve gelişen araç teknolojisi ile (araç kameraları, park sensörleri, vb.) park edebilmenin insan becerisinden daha çok araç teknolojisi ile yapılabilir olduğu günümüzde, tecrübe ile gelişecek park edebilme yetisinin test edilmesinin sınavda gereğinden fazla baskın bir değerlendirme önermesi olduğu düşünülmektedir.

Analiz sonucu önemli azınlık içine giren ilk kalkış hatalarının bu denli fazla olmasının sebeplerinden birinin sürücü adayının sınav kaygısından kaynaklandığı düşünülmektedir. $\mathrm{Bu}$ nedenle direksiyon eğitim programı içine sınav kaygısı ile baş edebilme yöntemlerinin anlatıldığ bir program eklenmesi önerilmektedir.

Yapılan analiz sonucunda sürücü adaylarının aracı ve araç elemanlarını yeteri kadar tanımadıkları görülmüştür. Aracı tam olarak tanımadan o araca tam anlamıyla hakim olabilmenin zor olduğu düşünüldüğünden verilen teorik ve pratik eğitimlerde bu konuya daha fazla önem verilmesi önerilmektedir.

Pareto analizi sonucu "geri geri giderken sağa sola dönme hataları" \%80'lik hata oranı içinde yer almaktadır. $\mathrm{Bu}$ sonuç değerlendirildiğinde verilen pratik eğitimde araçla geri gidiş ve dönüş çalışmalarına daha fazla zaman ayırılması önerilmektedir.

İstatistiksel proses kontrolünün önde gelen isimlerinden Kaoru Ishıkawa'ya göre; Pareto analizi en çok zarar veren hatayı veya hataları kolayca tespit etmenin yanında, bir iyileştirme programının vermekte olduğu sonuçların izlenmesinde de kullanılabilir. İlk Pareto'da tespit edilen hatalara çözüm getirildikçe Pareto diyagramındaki hata sıralaması değişmeye başlar. Böylece araştırmacı hataları tespit etmek için oluşturduğu grafiğe bakarak iyileşmenin etkilerini gözleme firsatı bulur (Özcan, 2001). Bu nedenle yapılan bu çalışma konudaki ilk Pareto olmasıyla önem taşımakta ve sistemde yapılacak iyileştirmeler sonrası yapılacak benzer çalışmalara temel oluşturacağı düşünülmektedir. 


\section{Kaynakça}

Aşıkkaya İ. (1995). Ülkemizdeki sürücü kurslarındaki eğitimin yeterliliğinin istatistiksel analizi (Yayınlanmamış yüksek lisans tezi). Gazi Üniversitesi, Ankara.

Başaran, N. (2010). Uluslararası kalite yönetimi bilim dalı Kalite iyileştirmede istatistiksel proses kontrol tekniklerinden pareto analizi ve gıda sektöründe bir uygulama (Yayınlanmamış yüksek lisans tezi). Marmara Üniversitesi, İstanbul.

Bozanoğlu, İ. (2005). Bilişsel davranışçı yaklaşıma dayalı grup rehberliğinin güdülenme, benlik saygısı, başarı ve sınav kaygısı düzeylerine etkisi. Ankara Üniversitesi Eğitim Bilimleri Fakültesi Dergisi, 38(1), 17-42.

Craft, R. ve Leake, C. (2002). The Pareto principle in organizationel decision making. Management Decision, 40 (8), 729-733.

Doğru, G. (2018). Motorlu taşıtlar sürücü kursiyerleri teorik sınavı ile elektronik sınavının çeşitli değişkenler açısından karşılaştırılması (Yayınlanmamış yüksek lisans tezi). Afyon Kocatepe Üniversitesi, Afyon.

Gülecen, M. (1998). Trafik eğitiminde sürücü kurslarının etkisi (Yayınlanmamış yüksek lisans tezi). Gazi Üniversitesi, Ankara.

Güleç, A. (2011). Ankara'daki özel sürücü kurslarının performans değerlendirmesi (Yayınlanmamış yüksek lisans tezi). Gazi Üniversitesi, Ankara.

Kujala, C., Weckström, M., Mladenovic, M.N. ve Saramaki, J., (2018). Travel times and transfers in public transport: Comprehensive accessibility analysis based on Paretooptimal journeys. Computers, Environment and Urban Systems. 67, 41-54. https://doi.org/10.1016/j.compenvurbsys.2017.08.012

Mc Cann, D. (2001). 80-20 vision. Dairy Industries International, 66(9), 25.

Özcan, S. (2001) İstatistiksel proses kontrol tekniklerinden pareto analizi ve çimento sanayiinde bir uygulama. C. ̈̈. İktisadi ve İdari Bilimler Dergisi, 2(2), 151-174.

Sazak, N. ve Ece S. (2004). Bolu Anadolu Güzel Sanatlar Lisesi Öğrencilerinin Öss ve Özel Yetenek Sınavlarına Yönelik Kaygıları. Musiki Muallim Mektebinden Günümüze Müzik Öğretmeni Yetiştirme Sempozyumu, 7-10 Nisan 2004, Süleyman Demirel Üniversitesi, Isparta.

Selbes, C. (2008). Türkiye'de sürücü eğitim müfredat programı ile sürücü belgesi alma prosedürünün Avrupa Birliği ülkeleri ile karşılaştırılması (Yayınlanmamış yüksek lisans tezi). Gazi Üniversitesi, Ankara.

Selvi, H. (2009). Stufflebeam'in program değerlendirme modeli ile Milli Ĕ̆itim Bakanlı̆̆ sürücü kurslarında kullanılan sürücü eğitim programının değerlendirilmesi (Yayınlanmamış yüksek lisans tezi). Abant İzzet Baysal Üniversitesi, Bolu.

Tatikonda, L.U., O’Brien, D. ve Tatikonda, R.J. (1999). Succeeding with 80/20. Management Accounting, 80(8), 8-12.

Vursavaş, F. (2004). Sürücü eğitim programının değerlendirilmesi (Yayınlanmamış yüksek lisans tezi). Ankara Üniversitesi, Ankara.

Ziarati, R. (2006) Safety At Sea - Applying Pareto Analysis. Proceedings of World Maritime Technology Conference, London, UK. 
Zinebi, K., Souissi, N. ve Tikito, K. (2018). Selecting qualitative features of driver behavior via pareto analysis. International ournal of Modern Education and Computer Science, 10(10), 1-10. doi: 10.5815/ijmecs.2018.10.01 
Ek 1. Direksiyon Eğitimi Sınav Değerlendirme Formu

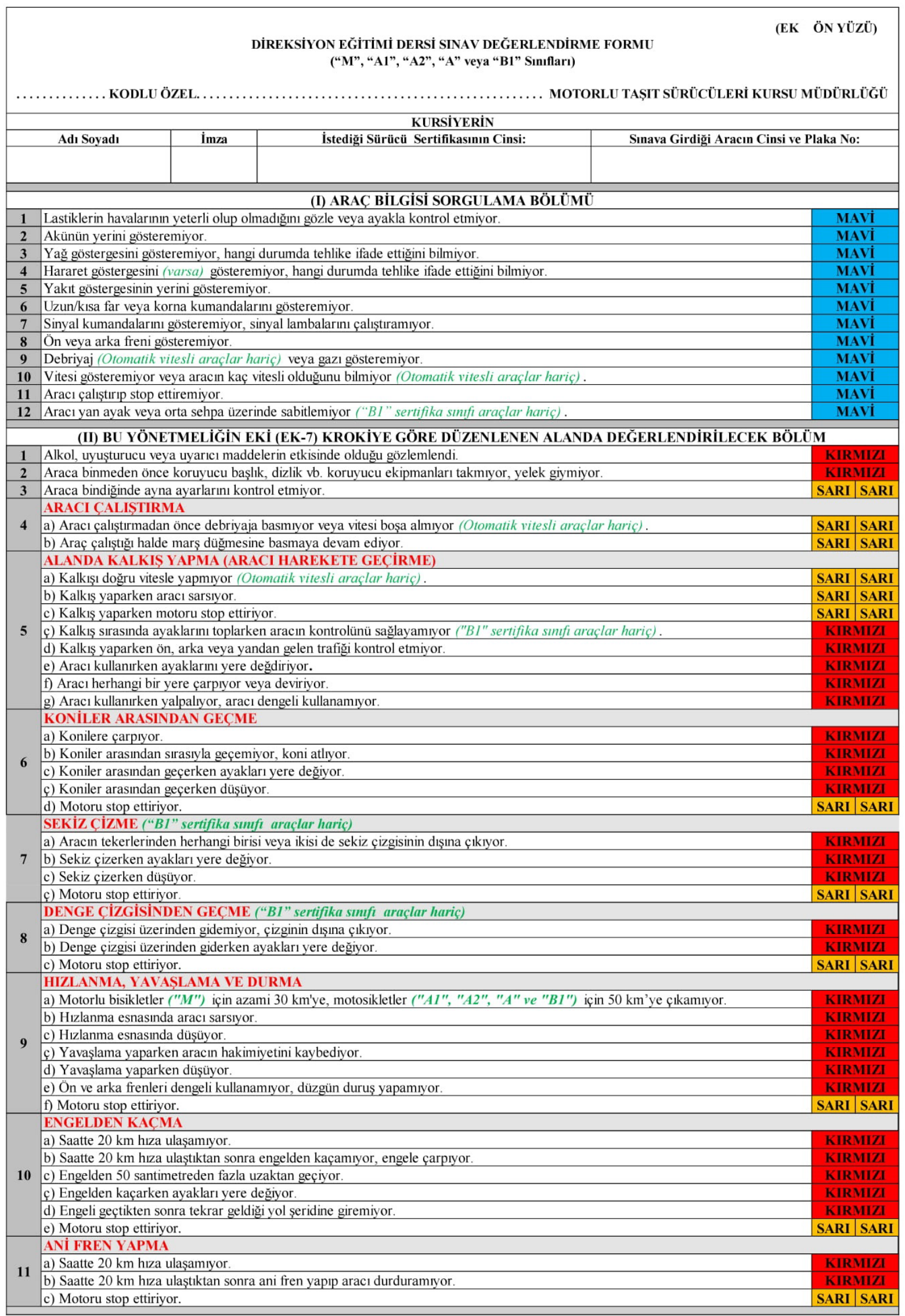


EK (ARKA YÜZÜ)
(III) AKAN TRAFIKTE SÜRÜS BECERISİ VE TRAFIK ALGISINA YÖNELIK DAVRANIȘLAR BÖLÜMÜ AKAN TRAFIKTE KALKIS YAPMA (ARACI HAREKETE GECIRME)

a) Kalkıșı doğru vitesle yapmıyor (Otomatik vitesli araçlar hariç).

b) Kalkıs yaparken aracı sarsıyor.

c) Kalkıs yaparken motoru stop ettiriyor.

12 c) Kalkıs yaparken omuz üstü bakis ile kör nokta kontrolü yapmior.

d) Kalkıs yaparken aynaları ile trafiği kontrol etmiyor.

e) Kalkıs yaparken sinyal vermiyor

f) Trafiği tehlikeye düșürecek șekilde hızlı ve kontrolsüz çıkıs yapıyor

g) Kalkıs yaptıktan sonra aracı doğru șeride konumlandıramıyor.

ARAC KUMANDA PEDALLARINA INTIBAK

a) Vites değiștirirken debriyaja tam basmıor (Otomatik vitesli araçlar hariç)

13 b) Vites değiștirirken gazı doğru kullanamıor (Otomatik vitesli araçlar hariç).

c) Vites değiștirirken aracm kontrolünü kaybediyor (Oı⿻matik viresli araçlar hariç).

c) Seyir halindeyken yola bakmayı bırakıp vitese bakarak vites değiștiriyor (Otomatik vitesli araçlar hariç).

d) Hızlanma ve yavaşlamalarda aracın hızını ayarlayamıyor. Gaz ve frene tam intibak edemiyor.

ȘERIT IZLEME VE DEGISTTIRME

a) Şerit değiștirmeden önce aynaları ile trafik kontrolü etmiyor

b) Serit deăistirmeden önce omuz üstü bakisı ile kör nokta kontrolü yapminor.

c) Şerit değiştirmeden önce zamanında sinyal vermiyor.

c) Şeridini degiștirirken yoldaki kesik ve sürekti çizgilerin anlamlarına uygun hareket etmiyor.

d) Serit izleme kurallarma uymuyor, şerit çizgilerinin içinde araç kullanmıyor.

e) Emniyet șeridini ihlal ediyor.

KAVSAKLARA YAKLASMA VE KAVSAKLARDA SAĞA SOLA DÖNÜSLER

a) Kavşağa yaklaşırken yavaşlamıor.

b) Kavşağa yaklaşırken döneceği yöne uygun șeride zamanında girmiyor

c) Dönüș öncesinde zamanında sinyal vermiyor.

15 c) Kavşakta karşıdan veya yandan gelen araçları kontrol etmiyor.

d) Kavșakta geçiș hakkı kurallarına uymuyor

e) Sağa sola dönüșlerden önce aynaları ile trafiği kontrol etmiyor.

f) Sağa sola dönüșlerden önce omuz üstü bakış ile kör nokta kontrolü yapmıyor

g) Dönüşünü tamamladıktan sonra yönüne uygun şeride girmiyor

ÖNÜNDEKI ARACI GECME (SOLLAMA YAPMA)

a) Sollamaya bașlamadan önce aynaları ile trafiği kontrol etmiyor.

b) Sollamaya bașlamadan önce omuz üstü bakıșı ile kör nokta kontrolü yapmiyor

16 c) Sollamaya başlamadan önce zamanında sinyal vermiyor.

c) Sollama yaparken önündeki veya diğer șeritlerdeki araçları tehlikeye atıyor.

d) Sollama yaparken kendi hızını ve diğer araçları hızlarımı dikkate almıyor.

e) Kendisini geçmek isteyen araç olduğunda geçilme kurallarma uymuyor.

HIZ KURALLARI

a) Hız levhalarına uymuyor, azami hı sıırını aşıyor.

17 b) Yaya, okul, bisiklet vb. geçitlere yaklașırken hızını azaltmıyor.

c) Yol için belirlenen asgari hız smırlarına uymuyor, çok yavaş araç kullanıyor.

c) Sürekli aynı vitesle araç kullanıyor, zamanında vites değiștirmiyor (Otomatik vitesli araçlar hariç).

d) Hızlanma ve yavașlamalarda aracın hızını ayarlayamıyor

CEVREYE DUYARLI VE EKONOMIK ARAC KULLANMA

18 a) Aracı yüksek devirde kullanıor. (Otomatik vitesli araçlar hariç).

b) Kornayı gereksiz yere kullaniyor.

c) Duruş ve kalkıșları ani yapıyor, aracı ekonomik kullanmıyor.

ARAC SEYIR HAL INDEYKEN DEĞERIENDiRIIECEK DIĞER DAVRANISLAR

a) Ișıklı trafik cihazları, trafik levhaları veya diğer trafik işaretlerine uymuyor

b) Araç kullanımı sırasında araç hakimiyetini veya trafik güvenliğini tehlikeye düşürecek düzeyde heyecanlı ve telaşlı olduğu görüldü.

c) Trafik polisini, yol ikaz ve değişikliklerini veya diğer yönlendirmeleri fark etmiyor.

c) Araç seyir halindeyken aynalardan trafiğin akıșını kontrol etmiyor.

19 d) Takip mesafesini kurallara uygun olarak ayarlayamiyor

e) Gecis üstünlüğüne sahip araclara gecis hakkı vermiyor.

f) Yaya ve okul geçitlerinde yayalara ve bisikletlilere geçiş hakkı vermiyor

g) Hemzemin geçitlerde geçiş kurallarma uymuyor

g) Komisyon bașkanımın telsizle verdiği talimatlara uymuyor

h) Genel olarak araç kullanma becerisi zayıf.

1) Güzergahı bilmiyor, güzergah dıșına çıkıyor.

DURAKLAMA VE PARK ETME

a) Duraklama veya park yasağına uymuyor

b) Duraklama veya park etmede sağ tarafa yanașriken sinyal vermiyor.

c) Duraklamadan veya park etmeden önce aynaları ile trafik kontrolü yapmıyor.

20 c) Park etme esnasında kaldırıma çarpiyor.

d) Duraklama veya park etmede șeridin sağına veya kaldırıma yeterince yanașmıyor.

e) Ani duruş yapıyor

f) Aracı terketmeden önce motoru stop etmiyor

g) Aracı terkederken yan ayak veya orta sehpa üzerinde sabitlemiyor ("B1" sertifika sunıfi araçlar hariç)

g) Aracı güvenli bir șekilde terk etmiyor

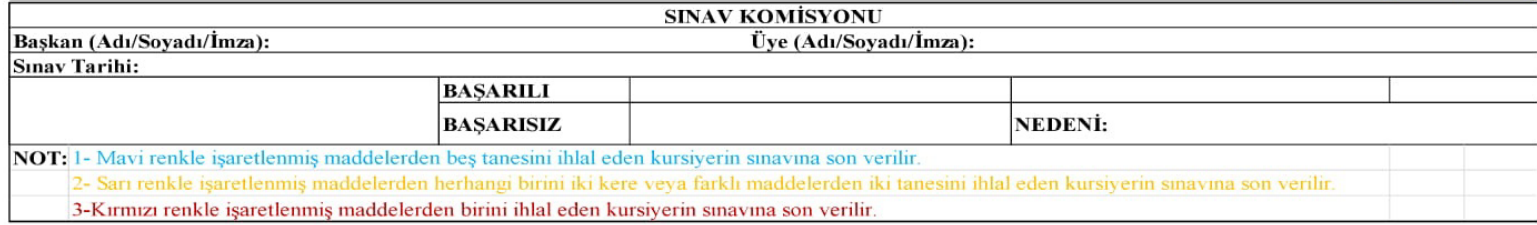

